\title{
Vibrio hispanicus sp. nov., isolated from Artemia sp. and sea water in Spain
}

Correspondence

B. Gomez-Gil

bruno@victoria.ciad.mx

\author{
B. Gomez-Gil, ${ }^{1}$ F. L. Thompson, ${ }^{2,3}$ C. C. Thompson, ${ }^{2}$ A. Garcia-Gasca, ${ }^{1}$ \\ A. Roque ${ }^{1}$ and J. Swings ${ }^{2,3}$
}

${ }^{1}$ CIAD/Mazatlán Unit for Aquaculture, AP. 711, Mazatlán Sinaloa, Mexico 82000

${ }^{2,3}{ }^{2}$ Laboratory for Microbiology ${ }^{2}$ and BCCM ${ }^{\mathrm{TM}} / \mathrm{LMG}$ Bacteria Collection, Laboratory for Microbiology ${ }^{3}$, Ghent University, Ghent 9000, Belgium
Artemia spp. nauplii and cysts have a diverse bacterial composition and many of the genera and species are found commonly in sea water; it has therefore been suggested that the microflora of Artemia nauplii is influenced significantly by that of the surrounding water (Igarashi et al., 1989). Artemia spp. cysts have been found to contain few bacteria, i.e. less than one bacterium per cyst (Austin \& Allen, 1982; Dehasque et al., 1991); after hatching, bacterial density on TCBS agar (which presumably consists of vibrios) can increase dramatically to levels of $10^{3}$ c.f.u. per nauplius (Sahul Hameed \& Balasubramanian, 2000) or $10^{6}-10^{8}$ c.f.u.

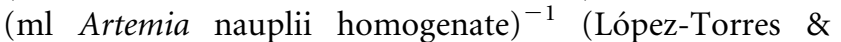
Lizárraga-Partida, 2001), and up to $10^{6}$ c.f.u. $\mathrm{ml}^{-1}$ in surrounding water (Austin \& Allen, 1982; Dehasque et al., 1991). This suggests that Vibrio spp. originate in sea water and then colonize Artemia when it hatches, exposing itself for the first time to the surrounding environment.

The taxonomic composition of Artemia bacterial cultures

Published online ahead of print on 22 August 2003 as DOI 10.1099/ ijs.0.02775-0.

Abbreviations: FAFLP, fluorescent AFLP; VR, variable region.

The GenBank/EMBL/DDBJ accession numbers for the 16S rRNA gene sequences of LMG $13240^{\top}$ clones 1 and 2 are AY254039 and AY254040, respectively.

A graph showing growth of Vibrio hispanicus sp. nov. at different $\mathrm{NaCl}$ concentrations is available as supplementary material in IJSEM Online. has been reported to contain a very high proportion of vibrios. In three marine fish hatcheries, $58-87 \%$ of isolates were identified as members of the genus Vibrio by fatty acid methyl ester analysis (Verdonck et al., 1994), although the proportion of vibrios in cysts is $<2 \%$ (Austin \& Allen, 1982; López-Torres \& Lizárraga-Partida, 2001) or nonexistent (Igarashi et al., 1989). These facts also support the theory that many of the vibrios found in Artemia spp. cultures come from sea water and not from Artemia cysts.

Strains LMG $13240^{\mathrm{T}}\left(=\mathrm{CAIM} 525^{\mathrm{T}}=\mathrm{VIB} 213^{\mathrm{T}}\right)$ and LMG 13213 ( = CAIM $524=$ VIB 186) were isolated from Artemia spp. during 1991. Strain LMG 13211 (=CAIM 523=VIB 184) was isolated from sea water in 1990. All strains were isolated in a fish hatchery in Barcelona, Spain, as described elsewhere (Verdonck et al., 1994). All strains have been deposited in the BCCM/LMG bacteria collection (Ghent, Belgium) and at the CAIM (Collection of Aquacultural Important Microorganisms; CIAD, A. C. Mazatlán, Mexico). These strains were previously analysed phenotypically (Austin et al., 1995; Vandenberghe et al., 2003) and with fluorescent AFLP (FAFLP) (Thompson et al., 2001). The patterns obtained by Austin et al. (1995) with the Biolog GN system clustered only with those of another four strains of the 260 Vibrio spp. strains that were analysed; one of these strains belongs to the recently described species Vibrio pacinii (Gomez-Gil et al., 2003), whereas Vandenberghe et al. (2003) clustered these strains only with 
the type strain of Vibrio gazogenes. All of these strains were shown to be pathogenic to the Atlantic salmon (Salmo salar) and had unique ribotyping patterns (Austin et al., 1995). Two of them (LMG 13213 and LMG $13240^{\mathrm{T}}$ ) also carried a $4.4 \mathrm{kbp}$ plasmid (Austin et al., 1995); analysis of these and many other Vibrio strains by FAFLP showed that these strains formed a unique cluster (A16; threshold delineation of $45 \%$ ) that was not associated with any type strain included in the analysis (Thompson et al., 2001).

Phenotypic characterization of the strains was performed as described previously (Gomez-Gil et al., 2003). Antibiotic sensitivity was estimated by the disc diffusion test (Bauer et al., 1966) on Iso-Sensitest agar (Oxoid) with $1.5 \%(\mathrm{w} / \mathrm{v})$ $\mathrm{NaCl}$. GLC analysis of methylated fatty acids was performed as described by Osterhout et al. (1991), but cells were grown on tryptic soy agar (TSA; Difco) with $1.5 \%(\mathrm{w} / \mathrm{v}) \mathrm{NaCl}$ and incubated at $28^{\circ} \mathrm{C}$. Growth of the three strains at different $\mathrm{NaCl}$ concentrations was tested in a microtitre plate (five replicates) with peptone water ( $1.5 \%$ Bactopeptone; Difco); inoculated plates were incubated for $48 \mathrm{~h}$ at $30^{\circ} \mathrm{C}$ and turbidity $\left(\mathrm{OD}_{610}\right)$ was measured.

Determination of the DNA G + C content of strain LMG $13240^{\mathrm{T}}$ was performed as described by Mesbah et al. (1989) and modified by Logan et al. (2000). DNA-DNA hybridization was done following the methodology described by Willems et al. (2001) at $39^{\circ} \mathrm{C}$.

The 16S rRNA gene was amplified with primers V16S-9F (5'-AGAGTTTGATCATGGCTCAG-3') and V16S-1491R (5'-AGCGCTACCTTGTTACGACTT-3'). The PCR mix contained $18.46 \mu \mathrm{l}$ water, $1.32 \mu \mathrm{l}$ dNTP mix $(2.5 \mathrm{mM}$ each), $2 \cdot 5 \mu \mathrm{l} 10 \times$ PCR buffer (with $25 \mathrm{mM} \mathrm{MgCl}_{2}$ ), $0 \cdot 26 \mu \mathrm{l}$ each primer $\left(0 \cdot 25 \mu \mathrm{g} \mu \mathrm{l}^{-1}\right), 0 \cdot 2 \mu \mathrm{l}$ Taq $\left(5 \mathrm{U}^{-1} \mathrm{l}^{-1}\right.$; Promega $)$ and $2 \cdot 0 \mu \mathrm{l}$ DNA (final volume, $25 \mu \mathrm{l}$ ). Amplification parameters were $94{ }^{\circ} \mathrm{C}$ for 2 min followed by 35 cycles of $94^{\circ} \mathrm{C}$ for $1 \mathrm{~min}, 60^{\circ} \mathrm{C}$ for $1 \mathrm{~min}$ and $72{ }^{\circ} \mathrm{C}$ for $1 \mathrm{~min}$, and a final extension of $72^{\circ} \mathrm{C}$ for $5 \mathrm{~min}$, rendering a $\sim 1.5 \mathrm{kbp}$ product. Purified PCR products were ligated into a pGEM-T cloning vector (Promega). Transformation was performed by heat shock at $37^{\circ} \mathrm{C}$ for $20 \mathrm{~s}$ by using competent cells of Escherichia coli DH5 $\alpha$ (Gibco/Invitrogen). Cells were then incubated at $37^{\circ} \mathrm{C}$ in SOC medium for $1 \mathrm{~h}$, centrifuged, plated on Luria-Bertani medium (Invitrogen) that contained ampicillin $\left(60 \mu \mathrm{g} \mathrm{ml}^{-1}\right)$ and incubated overnight at $37^{\circ} \mathrm{C}$. Plasmid extraction was performed by using a miniprep kit (Promega) according to the instructions of the manufacturer. Positive clones were identified by EcoRI digestion and gel electrophoresis. Bidirectional sequencing was carried out by using labelled T7/SP6 universal primers and a LiCor $I^{2}$ DNA sequencer, as described by the manufacturer.

The 16S rRNA gene sequence of LMG $13240^{\mathrm{T}}$ type 1 (GenBank accession no. AY254039) was also compared to the sequences deposited in GenBank (BLASTN; Altschul et al., 1990) and the Ribosomal Database Project II (RDP; Sequence Match version 2.7; Cole et al., 2003). Sequences were aligned with CLUSTALX (version 1.8; Thompson et al., 1997). Tree topology (neighbour-joining; Saitou \& Nei, 1987) and stability of groupings (bootstrap analysis, 1000 replicates) of the closest phylogenetic species (with Vibrio cholerae $\mathrm{El}$ Tor strain as the outlier) and sequence similarities within the genus Vibrio (Jukes-Cantor model; $\Gamma=0 \cdot 4$; pairwise deletion; 1000 bootstrap replications; random number seed, 67137) were calculated with the MEGA program (version 2.1; Kumar et al., 2001).

Phenotypic characters, including fatty acid proportions (Bertone et al., 1996), of the three strains analysed placed Vibrio hispanicus sp. nov. as a member of the genus Vibrio (see species description). Their phenotypic characteristics also permit clear differentiation from related species (Table 1), especially growth without $\mathrm{NaCl}$, arginine dihydrolase and lysine and ornithine decarboxylase.

Members of the genus Vibrio require $\mathrm{Na}^{+}$for growth, with a few exceptions: V. cholerae, Vibrio mimicus and some strains of Vibrio fluvialis, Vibrio furnissii and Vibrio metschnikovii (Alsina \& Blanch, 1994), although V. fluvialis and $V$. furnissii may need small amounts of $\mathrm{Na}^{+}$to grow (Farmer \& Hickman-Brenner, 1992). Optimal $\mathrm{Na}^{+}$concentration for many marine bacteria is $70-300 \mathrm{mM}$ (Reichelt \& Baumann, 1974), which is well below that of sea water (450-480 $\mathrm{mM}$ ), although many vibrios have been isolated from hypersaline environments $(4185 \mathrm{mM})$, from which Artemia cysts are also harvested (Straub \& Dixon, 1993). The strains analysed here were able to grow at $1.0 \mathrm{mM} \mathrm{NaCl}$, but best growth was obtained at $1024 \mathrm{mM}$ and no growth was detected at $2048 \mathrm{mM}$ (see Supplementary Figure in IJSEM Online).

Table 1. Phenotypic differences between $V$. hispanicus sp. nov. and related arginine dihydrolase-positive, lysine and ornithine decarboxylase-negative Vibrio species that grow in the absence of $\mathrm{NaCl}$

Taxa are indicated as: 1, V. hispanicus sp. nov.; 2, V. diazotrophicus; 3, V. fluvialis; 4, V. furnissii; 5, V. metschnikovii. +, Positive; -, negative; (+), positive for $75-89 \%$ of strains; (-), negative for $25-11 \%$ of strains; V, variable. Data from Alsina \& Blanch (1994) and Holt et al. (1994).

\begin{tabular}{|lccccc|}
\hline Test & $\mathbf{1}$ & $\mathbf{2}$ & $\mathbf{3}$ & $\mathbf{4}$ & $\mathbf{5}$ \\
\hline Growth at: & & & & & \\
$\quad 0 \% \mathrm{NaCl}$ & + & - & $\mathrm{V}$ & $\mathrm{V}$ & $\mathrm{V}$ \\
$\quad 4{ }^{\circ} \mathrm{C}$ & + & $(+)$ & - & - & $\mathrm{V}$ \\
Indole & + & + & $(+)$ & $(-)$ & $(-)$ \\
Oxidase & + & + & + & + & - \\
Gas from glucose & - & - & - & + & - \\
Resistance to O/129 $(10 \mu \mathrm{g})$ & - & $\mathrm{V}$ & + & + & $\mathrm{V}$ \\
Gelatinase & - & - & + & $(+)$ & + \\
Utilization of L-rhamnose & + & - & - & - & - \\
\hline
\end{tabular}


$16 \mathrm{~S}$ rRNA gene sequences of the strains analysed placed them in the genus Vibrio; their closest phylogenetic neighbours were Vibrio proteolyticus $(97 \cdot 6 \%$ BLASTN, 0.906 RDP), Vibrio diazotrophicus (97.9\% BLASTN, 0.900 RDP), Vibrio campbellii (96.8\% BLASTN, 0.857 RDP), Vibrio alginolyticus (96.8\% BLASTN, 0.876 RDP), Vibrio natriegens $(96.7 \%$ BLASTN, 0.867 RDP), Vibrio parahaemolyticus (96.6\% BLASTN, 0.871 RDP), Vibrio nigripulchritudo (96.6\% BLASTN, 0.882 RDP), Vibrio vulnificus $(97 \cdot 1 \%$ BLASTN, 0.867 RDP) and Vibrio harveyi (96.4\% BLASTN, $0 \cdot 875$ RDP). Phylogenetic analysis with the neighbourjoining method (Fig. 1) clustered $V$. hispanicus sp. nov. strains close to the Vibrio core group (Dorsch et al., 1992). Strain LMG $13240^{\mathrm{T}}$ produced two different $16 \mathrm{~S}$ rRNA gene sequences, which differed by 15 bases $(0.99 \%)$; five bases were within variable region (VR-) 1, five bases were within VR-7 and five bases were scattered in conserved regions.

DNA G $+\mathrm{C}$ content was $42 \cdot 8 \mathrm{~mol} \%$, a value that lies within the range of the genus Vibrio (38-51\%; Farmer, 1992). DNA-DNA similarities of strains LMG $13240^{\mathrm{T}}$ and LMG 13211 with the species that was related most closely by $16 \mathrm{~S}$ rRNA gene sequence similarity, V. proteolyticus LMG $3772^{\mathrm{T}}$, gave 22.5 and $22.7 \%$, respectively. Hybridizations were performed with other closely related species: $V$. harveyi LMG $4044^{\mathrm{T}}$ (24.7 and $26 \cdot 4 \%$, respectively), V. nigripulchritudo LMG $3896^{\mathrm{T}}$ (18.3 and $20 \cdot 9 \%$, respectively) and $V$. natriegens LMG $10935^{\mathrm{T}}$ (23.9 and $24.2 \%$, respectively). Hybridization was $102.5 \%$ between strains LMG $13240^{\mathrm{T}}$ and LMG 13211 and 30.6\% between V. proteolyticus LMG

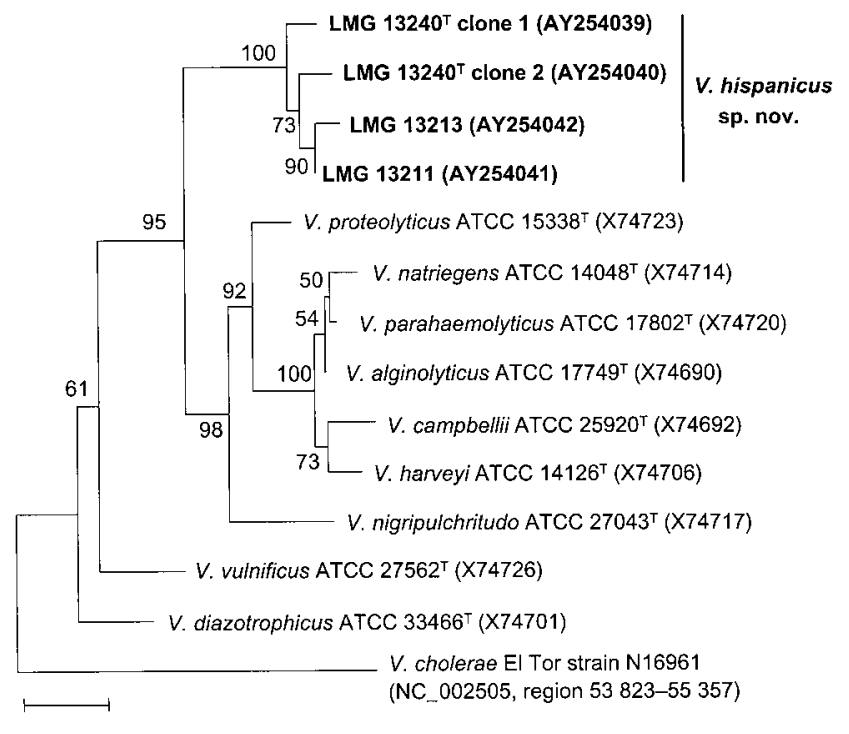

Fig. 1. Phylogenetic dendrogram of Vibrio hispanicus sp. nov. strains with the most closely related Vibrio species, based on almost-complete $16 \mathrm{~S}$ rRNA gene sequences (1519 bp) and constructed by the neighbour-joining method (pairwise deletion, Kimura two-parameter, $\Gamma=0 \cdot 4)$. Numbers at nodes indicate level of bootstrap support (1000 replicates). Bar, $1 \%$ divergence.
$3772^{\mathrm{T}}$ and $V$. harveyi LMG $4044^{\mathrm{T}}$. The range of $16 \mathrm{~S}$ rRNA gene sequence similarity within the Vibrio genus for V. hispanicus LMG $13240^{\mathrm{T}}$ was $22-88 \%$.

The data presented here, including phenotypic characteristics, 16S rRNA gene sequence analysis and DNA-DNA hybridization, and that of FAFLP fingerprinting that was published previously (Thompson et al., 2001), clearly support the identity of strains LMG $13240^{\mathrm{T}}$, LMG 13211 and LMG 13213 as members of a novel species of the genus Vibrio, for which the name Vibrio hispanicus sp. nov. is proposed.

\section{Description of Vibrio hispanicus sp. nov.}

Vibrio hispanicus (his.pa'ni.cus. L. masc. adj. hispanicus from Spain).

Gram-negative, small $(2 \cdot 2 \pm 0 \cdot 659 \mu \mathrm{m})$, motile, curved rods with polar flagellation. Bright yellow, small (1-3 mm), circular colonies are formed on TCBS agar. Non-luminescent, translucent and non-swarming colonies are formed on marine agar. Growth occurs in media that contain $0,2 \cdot 5$, $6 \cdot 0,8 \cdot 0$ and $10 \% \mathrm{NaCl}(\mathrm{w} / \mathrm{v})$, but not in $12 \cdot 0 \% \mathrm{NaCl}$. Growth occurs at $4,30,35$ and $40{ }^{\circ} \mathrm{C}$. Positive for oxidase, indole, citrate, methyl red, nitrite reduction and $\alpha$ galactosidase. Fermentative, arginine dihydrolase-positive, lysine and ornithine decarboxylase- and L-tyrosine-negative. Tryptophan deaminase, $\mathrm{H}_{2} \mathrm{~S}$, gas from glucose production, Voges-Proskauer reaction, gelatinase and urease are negative. Susceptible to vibriostatic agent O/129 at 10 and $150 \mu \mathrm{g}$ and to polymixin $\mathrm{B}$ at $300 \mathrm{U}$, but resistant to streptomycin $(25 \mu \mathrm{g})$ and gentamicin $(10 \mu \mathrm{g})$. Positive for $\alpha$-D-glucose, $\beta$-hydroxybutyric acid, methyl $\beta$-D-glucoside, D-glucuronic acid (LMG 13213 is weakly positive), cellobiose, DL-lactic acid, dextrin, D-fructose, D-galactose, D-gluconic acid, D-mannitol, D-mannose, D-raffinose (LMG $13240^{\mathrm{T}}$ and LMG 13213 are weakly positive), D-saccharic acid (LMG 13213 is weakly positive), D-trehalose, gentiobiose, inosine, $\mathrm{L}$-asparagine, $\mathrm{L}$-aspartic acid (LMG $13240^{\mathrm{T}}$ is weakly positive), L-glutamic acid, L-rhamnose, L-serine, maltose, methyl pyruvate, $N$-acetyl-D-glucosamine, psicose, sucrose, thymidine and uridine utilization as sole carbon sources. Negative for 2,3-butanediol, 2-aminoethanol, acetic acid, adonitol, alaninamide, $\alpha$-cyclodextrin, $\alpha$-Dlactose lactulose, $\alpha$-hydroxybutyric acid, $\alpha$-ketobutyric acid, $\alpha$-ketoglutaric acid, $\alpha$-ketovaleric acid, bromosuccinic acid, cis-aconitic acid, citric acid, DL- $\alpha$-glycerol phosphate, DLcarnitine, D-alanine, D-arabitol, D-galactonic acid lactone, D-galacturonic acid, D-glucosaminic acid, D-melibiose, D-serine, D-sorbitol, formic acid, $\gamma$-aminobutyric acid, $\gamma$-hydroxybutyric acid, glucose 1-phosphate, glucose 6phosphate, glucuronamide, glycogen, glycyl L-aspartic acid, glycyl L-glutamic acid, hydroxy L-proline, i-erythritol, itaconic acid, L-alanine, L-alanylglycine, L-fucose, L-histidine, L-leucine, L-ornithine, L-phenylalanine, L-proline, Lpyroglutamic acid, L-threonine, malonic acid, myo-inositol, monomethyl succinate, $\mathrm{N}$-acetyl-D-galactosamine, phenylethylamine, p-hydroxyphenylacetic acid, propionic acid, 
putrescine, quinic acid, sebacic acid, succinamic acid, turanose, Tween 40, Tween 80, urocanic acid and xylitol as sole carbon sources. Acid and alkaline phosphatases, $\beta$-glucosidase, esterase, esterase lipase, leucine arylamidase and naphthol-AS-BI-phosphohydrolase are positive; $\alpha$ chymotrypsin, $\alpha$-fucosidase, $\alpha$-glucosidase, $\alpha$-mannosidase, $\beta$-galactosidase, $\beta$-glucuronidase, cystine arylamidase, lipase, $N$-acetyl- $\beta$-glucosaminidase, trypsin and valine arylamidase are negative. Most abundant fatty acids (\% of total fatty acids) are, in descending order (mean of three strains, minimum and maximum): summed feature 3 $\left(\mathrm{C}_{16: 1} \omega 7 c\right.$ and/or iso- $\left.\mathrm{C}_{15: 0} 2-\mathrm{OH} ; 37 \cdot 2,35 \cdot 8-39 \cdot 1\right), \mathrm{C}_{16: 0}$ $(25 \cdot 7,22 \cdot 8-27 \cdot 9), \mathrm{C}_{18: 1} \omega 7 c(16 \cdot 7,15 \cdot 5-17 \cdot 8), \mathrm{C}_{14: 0}(5 \cdot 9$, $5 \cdot 3-6 \cdot 5), \mathrm{C}_{12: 0}(4 \cdot 4,4 \cdot 2-4 \cdot 8)$, summed feature $2\left(\mathrm{C}_{14: 0}\right.$ $3-\mathrm{OH}$ and/or iso- $\left.\mathrm{C}_{16: 1} \mathrm{I} ; 3 \cdot 2,3 \cdot 1-3 \cdot 4\right), \mathrm{C}_{12: 0} 3-\mathrm{OH}(2 \cdot 6$, $2 \cdot 5-2 \cdot 8)$ and $\mathrm{C}_{18: 0}(1 \cdot 1,0 \cdot 9-1 \cdot 2)$. Differences between strains analysed are: LMG $13240^{\mathrm{T}}$ does not utilize $\alpha$-lactose, LMG 13211 does not utilize glycerol or amygdalin and LMG 13213 does not utilize succinic acid. LMG 13213 is sensitive to ampicillin ( $30 \mu \mathrm{g}$; the others are intermediately resistant) and is intermediately resistant to kanamycin (30 $\mu \mathrm{g}$; the others are resistant) and oxytetracycline (30 $\mu \mathrm{g}$; the others are resistant); LMG 13211 is resistant to amikacin (30 $\mu \mathrm{g}$; the others are intermediately resistant). DNA G + C content is $42 \cdot 8 \mathrm{~mol} \%$.

The type strain is LMG $13240^{\mathrm{T}}\left(=\mathrm{CAIM} 525^{\mathrm{T}}=\right.$ VIB $213^{\mathrm{T}}$ ) and reference strains are LMG 13211 (=CAIM 523) and LMG 13213 (=CAIM 524). All were isolated from Artemia sp. and its culture water in Barcelona, Spain.

\section{Acknowledgements}

This study was financed by CONACyT (Mexico) project J-28344 to B. G., Conselho Nacional de Desenvolvimento Científico e Tecnológico (CNPq, Brazil) as PhD scholarship no. 2008361/98-6 for F. L. T. and grants from the Fund for Scientific Research FWO (Belgium) to J.S. Thanks to Cipatli Meza C., Carmen Bolan M. and Roxana Atondo.

\section{References}

Alsina, M. \& Blanch, A. R. (1994). A set of keys for biochemical identification of environmental Vibrio species. J Appl Bacteriol 76, 79-85.

Altschul, S. F., Gish, W., Miller, W., Myers, E. W. \& Lipman, D. J. (1990). Basic local alignment search tool. J Mol Biol 215, 403-410.

Austin, B. \& Allen, D. (1982). Microbiology of laboratory-hatched brine shrimp (Artemia). Aquaculture 26, 369-383.

Austin, B., Alsina, M., Austin, D. A. \& 10 other authors (1995). Identification and typing of Vibrio anguillarum: a comparison of different methods. Syst Appl Microbiol 18, 285-302.

Bauer, A. W., Kirby, W. M., Sherris, J. C. \& Turck, M. (1966). Antibiotic susceptibility testing by a standardized single disk method. Am J Clin Pathol 45, 493-496.

Bertone, S., Giacomini, M., Ruggiero, C., Piccarolo, C. \& Calegari, L. (1996). Automated systems for identification of heterotrophic marine bacteria on the basis of their fatty acid composition. Appl Environ Microbiol 62, 2122-2132.
Cole, J. R., Chai, B., Marsh, T. L. \& 8 other authors (2003). The Ribosomal Database Project (RDP-II): previewing a new autoaligner that allows regular updates and the new prokaryotic taxonomy. Nucleic Acids Res 31, 442-443.

Dehasque, M., Verdonck, L., Sorgeloos, P., Swings, J., Léger, P. \& Kersters, K. (1991). Determination of the bacterial contamination in live food production systems in marine fish hatcheries in southern Europe. In LARVI '91 (Special Publication of the European Aquaculture Society no. 15), pp. 339-402. Edited by P. Lavens, P. Sorgeloos, E. Jaspers \& F. Ollevier. Ghent, Belgium: European Aquaculture Society.

Dorsch, M., Lane, D. \& Stackebrandt, E. (1992). Towards a phylogeny of the genus Vibrio based on $16 \mathrm{~S}$ rRNA sequences. Int J Syst Bacteriol 42, 58-63.

Farmer, J. J. (1992). The family Vibrionaceae. In The Prokaryotes. A Handbook on the Biology of Bacteria: Ecophysiology, Isolation, Identification, Applications, pp. 2938-2951. Edited by A. Balows, H. G. Trüper, M. Dworkin, W. Harder \& K. H. Schleifer. New York: Springer.

Farmer, J. J. \& Hickman-Brenner, F. W. (1992). The genera Vibrio and Photobacterium. In The Prokaryotes. A Handbook on the Biology of Bacteria: Ecophysiology, Isolation, Identification, Applications, pp. 2952-3011. Edited by A. Balows, H. G. Trüper, M. Dworkin, W. Harder \& K. H. Schleifer. New York: Springer.

Gomez-Gil, B., Thompson, F. L., Thompson, C. C. \& Swings, J. (2003). Vibrio pacinii sp. nov., from cultured aquatic organisms. Int J Syst Evol Microbiol 53, 1569-1573.

Holt, G. J., Krieg, N. R., Sneath, P. H. A., Staley, T. \& Williams, S. T. (editors) (1994). Bergey's Manual of Determinative Bacteriology, 9th edn. Baltimore: Williams \& Wilkins.

Igarashi, M. A., Sugita, H. \& Deguchi, Y. (1989). Microflora associated with eggs and nauplii of Artemia salina. Nippon Suisan Gakkaishi 55, 2045.

Kumar, S., Tamura, K., Jakobsen, I. B. \& Nei, M. (2001). MEGA2: molecular evolutionary genetic analysis software. Bioinformatics $\mathbf{1 7}$, $1244-1245$.

Logan, N. A., Lebbe, L., Hoste, B. \& 7 other authors (2000). Aerobic endospore-forming bacteria from geothermal environments in northern Victoria Land, Antarctica, and Candlemas Island, South Sandwich archipelago, with the proposal of Bacillus fumarioli sp. nov. Int J Syst Evol Microbiol 50, 1741-1753.

López-Torres, M. A. \& Lizárraga-Partida, M. L. (2001). Bacteria isolated on TCBS media associated with hatched Artemia cysts of commercial brands. Aquaculture 194, 11-20.

Mesbah, M., Premachandran, U. \& Whitman, W. B. (1989). Precise measurement of the $\mathrm{G}+\mathrm{C}$ content of deoxyribonucleic acid by high-performance liquid chromatography. Int J Syst Bacteriol 39, 159-167.

Osterhout, G. J., Shull, V. H. \& Dick, J. D. (1991). Identification of clinical isolates of gram-negative nonfermentative bacteria by an automated cellular fatty acid identification system. J Clin Microbiol 29, 1822-1830.

Reichelt, J. L. \& Baumann, P. (1974). Effect of sodium chloride on growth of heterotrophic marine bacteria. Arch Microbiol 97, 329-345.

Sahul Hameed, A. S. \& Balasubramanian, G. (2000). Antibiotic resistance in bacteria isolated from Artemia nauplii and efficacy of formaldehyde to control bacterial load. Aquaculture 183, 195-205.

Saitou, N. \& Nei, M. (1987). The neighbor-joining method: a new method for reconstructing phylogenetic trees. Mol Biol Evol 4, 406-425. 
Straub, D. V. \& Dixon, B. A. (1993). Bacteriological flora of the brine shrimp (Artemia franciscana) from a hypersaline pond in San Francisco Bay, California. Aquaculture 118, 309-313.

Thompson, J. D., Gibson, T. J., Plewniak, F., Jeanmougin, F. \& Higgins, D. G. (1997). The CLUSTAL_X windows interface: flexible strategies for multiple sequence alignment aided by quality analysis tools. Nucleic Acids Res 25, 4876-4882.

Thompson, F. L., Hoste, B., Vandemeulebroecke, K. \& Swings, J. (2001). Genomic diversity amongst Vibrio isolates from different sources determined by fluorescent amplified fragment length polymorphism. Syst Appl Microbiol 24, 520-538.
Vandenberghe, J., Thompson, F. L., Gomez-Gil, B. \& Swings, J. (2003). Phenotypic diversity amongst Vibrio isolates from marine aquaculture systems. Aquaculture 219, 9-20.

Verdonck, L., Swings, J., Kersters, K., Dehasque, M., Sorgeloos, P. \& Leger, P. (1994). Variability of the microbial environment of rotifer Brachionis plicatilis and Artemia production systems. $J$ World Aquacult Soc 25, 55-59.

Willems, A., Doignon-Bourcier, F., Goris, J., Coopman, R., de Lajudie, P., De Vos, P. \& Gillis, M. (2001). DNA-DNA hybridization study of Bradyrhizobium strains. Int $J$ Syst Evol Microbiol 51, 1315-1322. 